\title{
Evaluasi penerimaan pajak kendaraan bermotor (PKB) dan bea balik nama kendaraan bermotor (BBN-KB) serta dampaknya terhadap pendapatan asli daerah di Provinsi Jambi
}

\author{
R. Ilham Asri Aditya*; Zulfanetti ; Heriberta \\ Prodi Magister Ilmu Ekonomi, Program Pascasarjana, Universitas Jambi \\ *E-mail korespodensi : asriilham88@gmail.com
}

\begin{abstract}
The purpose of this study was to analyze the factors supporting and inhibiting the achievement of revenue targets, the effectiveness of motor vehicle tax receipts and motor vehicle name transfer fees, and their relationship with the original income of Jambi Province. This study used a quantitative descriptive method, where the data obtained were analyzed using qualitative analysis techniques and quantitative analysis. The results of the qualitative analysis show that the determination of the target of motor vehicle tax revenue and motor vehicle name transfer fee in Jambi Province is still done manually based on the latest achievement/realization data plus the percentage that is expected to be achieved following the existing upward trend. from previous years. The results of the quantitative analysis show that the motor vehicle tax revenue and the transfer of motor vehicle name transfer duties in 2014-2018 in Jambi Province have not been effective following the potential for motor vehicle tax revenue and motor vehicle name transfer fee. Besides, there is also no significant relationship between the effectiveness of motor vehicle tax receipts and the effectiveness of the transfer of motor vehicle name transfer fees on the Regional Original Revenue of Jambi Province during 2014-2018, either partially or simultaneously.
\end{abstract}

Keywords: Motorized vehicle tax, Local revenue

\begin{abstract}
Abstrak
Tujuan penelitian ini adalah untuk menganalisis faktor-faktor pendukung dan penghambat pencapaian target penerimaan, efektivitas penerimaan pajak kendaraan bermotor dan bea balik nama kendaraan bermotor serta hubungannya dengan pendapatan asli Provinsi Jambi. Penelitian ini menggunakan metode deskriptif kuantitatif, dimana data yang diperoleh dianalisis dengan menggunakan teknik analisis kualitatif dan analisis kuantitatif. Hasil analisis kualitatif menunjukkan bahwa penetapan target penerimaan pajak kendaraan bermotor dan bea balik nama kendaraan bermotor di Provinsi Jambi masih dilakukan secara manual berdasarkan data capaian / realisasi terkini ditambah besarnya persentase yang diharapkan dapat dicapai sesuai dengan trend kenaikan yang ada. dari tahun-tahun sebelumnya. Hasil analisis kuantitatif menunjukkan bahwa penerimaan pajak kendaraan bermotor dan bea balik nama kendaraan bermotor tahun 2014-2018 di Provinsi Jambi belum efektif sesuai dengan potensi penerimaan pajak kendaraan bermotor dan bea balik nama kendaraan bermotor. Selain itu, juga tidak terdapat hubungan yang signifikan antara efektivitas penerimaan pajak kendaraan bermotor dengan efektivitas penerimaan bea balik nama kendaraan bermotor terhadap Pendapatan Asli Daerah Provinsi Jambi selama tahun 2014-2018, baik secara parsial maupun simultan.
\end{abstract}

Kata kunci: Pajak kendaraan bermotor, Pendapatan asli daerah 


\section{PENDAHULUAN}

Salah satu sumber pendapatan asli daerah dengan nilai kontribusi terbesar adalah pajak daerah, sebagaimana pendapat yang dinyatakan Mokoginta (2015) dalam penelitiannya bahwa pajak daerah merupakan komponen penting dalam PAD yang harus dikembangkan karena kontribusi yang diberikan terhadap pendapatan asli daerah cukup besar. Pajak daerah berperan serta dalam membiayai pembangun daerah, tanpa adanya pajak daerah, maka kebutuhan akan dana untuk pembangunan akan sulit untuk dipenuhi karena sebagian besar pendapatan negara maupun daerah berasal dari pajak, oleh sebab itu permasalahan tentang pajak ini harus ditangani secara tepat agar iuran pajak atau pun retribusi daerah dapat dimanfaatkan dengan baik.

Dalam Undang-Undang Nomor 28 Tahun 2009 Pajak Daerah dan Retribusi Daerah dibagi menjadi 5 jenis macam pajak, yaitu pajak kendaraan bermotor (PKB), bea balik nama kendaraan bermotor (BBNKB), pajak bahan bakar kendaraan bermotor, pajak air permukaan dan pajak rokok. Dari kelima jenis pajak tersebut, PKB dan BBNKB merupakan sumber pendapatan daerah Provinsi Jambi terbesar untuk sektor pajak daerah. Hal ini terjadi karena seiring dengan pertambahan penduduk setiap tahun, menyebabkan meningkatnya ketergantungan terhadap kebutuhan akan alat transportasi seperti kendaraan bermotor baik roda empat maupun roda dua. Hal tersebut didukung pula dengan berbagai kemudahan yang diberikan dealer dalam pembelian kendaraan bermotor sehingga masyarakat tertarik untuk memilikinya dan selera yang berubah-ubah seiring bergantinya zaman akan mengakibatkan mudahnya terjadi perpindahan kepemilikan suatu kendaraan bermotor dan memicu kepada pengenaan Bea Balik Nama Kendaraan Bermotor. Berdasarkan data pada Sistem Administrasi Manunggal di bawah Satu Atap (SAMSAT) Provinsi Jambi tercatat jumlah kendaraan bermotor atau wajib pajak pada tahun 2018 sebanyak 2.011.154 unit, yang terdiri atas 234.232 unit mobil dan 1.776.922 unit motor. Adapun jumlah kendaraan bermotor di Provinsi Jambi sepanjang tahun 2013 hingga 2018 adalah sebagai berikut:

Tabel 1. Jumlah kendaraan bermotor di Provinsi Jambi Tahun 2013-2018

\begin{tabular}{|c|c|c|c|c|c|c|}
\hline \multirow{2}{*}{$\begin{array}{c}\text { Jenis } \\
\text { kendaraan }\end{array}$} & \multicolumn{6}{|c|}{ Tahun / Jumlah kendaraan (Unit) } \\
\hline & 2013 & 2014 & 2015 & 2016 & 2017 & 2018 \\
\hline Mobil & 148.144 & 165.891 & 183.386 & 197.733 & 208.452 & 234.232 \\
\hline Motor & 1.294 .141 & 1.392 .955 & 1.482 .977 & 1.553 .723 & 1.605 .232 & 1.776 .922 \\
\hline Jumlah & 1.442 .285 & 1.558 .846 & 1.666 .363 & 1.751 .456 & 1.813 .684 & 2.011.154 \\
\hline
\end{tabular}

Sumber: Badan Pusat Statistik Provinsi Jambi, 2018(diolah)

Dengan potensi data wajib pajak Provinsi Jambi tersebut dapat memberikan informasi bahwa potensi pajak kendaraan bermotor dan bea balik nama kendaraan bermotor masih dapat ditingkatkan. Oleh karena itu, pemerintah Provinsi Jambi perlu melakukan upaya efektivitas dan efisiensi dalam pemungutan Pajak Kendaraan Bermotor dan bea balik nama kendaraan bermotor untuk meningkatkan pendapatan daerah. Adapun Dasar Pengenaan Pajak (DPP) yang digunakan dalam menghitung pajak kendaraan bermotor, menurut Samudra (2016:94) dihitung sebagai perkalian dari dua unsur pokok, yaitu; (1) nilai jual kendaraan bermotor (NJKB) dan (2) bobot yang mencerminkan secara relatif kadar kerusakan jalan dan pencemaran lingkungan sebagai akibat dari penggunaan 
kendaraan bermotor. Adapun nilai jual kendaraan bermotor dan bobot tersebut didasarkan kepada Harga Pasaran Umum atas suatu kendaraan bermotor.

Pelaksanaan pemungutan pajak kendaraan bermotor di Provinsi Jambi dipungut melalui kantor bersama Sistem Administrasi Manunggal Satu Atap (SAMSAT). Dalam pelaksanaan pemungutan Pajak Kendaraan Bermotor yang diselenggarakan oleh unit pelayanan Kantor Bersama SAMSAT ini melibatkan tiga instansi pemerintah, yaitu: Badan Keuangan Daerah, Polisi Republik Indonesia, dan PT. (Persero) Asuransi Kerugian Jasa Raharja. Dalam proses pencatatan dan pembayaran pajak kendaraan bermotor menggunakan Sistem Administrasi Manunggal di bawah Satu Atap (SAMSAT) dalam pengeluaran STNK (Surat Tanda Nomor Kendaraan), pembayaran Pajak, BBNKB (Bea Balik Nomor Kendaraan Bermotor) dan Sumbangan Wajib Dana Kecelakaan Lalu Lintas Jalan (SWDKLLJ), semuanya dilakukan dalam satu atap sehingga masyarakat mudah dalam memenuhi kewajibannya dalam membayar pajak kendaraan bermotor.

Data pada Tabel 2 menunjukkan bahwa realisasi penerimaan pajak kendaraan bermotor (PKB) selalu mengalami peningkatan dari tahun 2014 hingga 2018, dengan tingkat persentase ketercapaian dari target yang ditetapkan selalu di atas $100 \%$ setiap tahunnya. Merujuk pada data target dan realisasi penerimaan PKB tersebut jelas menunjukkan bahwa pemungutan pajak yang dilakukan oleh pemerintah Provinsi Jambi sudah berjalan dengan efektif. Sementara untuk realisasi penerimaan bea balik nomor kendaraan bermotor (BBNKB) mengalami fluktuasi sepanjang tahun 2014 sampai 2018. Dalam kurun waktu tiga tahun yaitu dari 2015 sampai 2017, realisasi penerimaan BBNKB cenderung mengalami penurunan, dengan rata-rata nilai penurunan sebesar 18,38 miliyar rupiah. Kemudian meningkat kembali pada tahun 2018 sebesar 85,54 miliyar rupiah. Merujuk pada data target dan realisasi penerimaan BBN-KB menunjukkan bahwa pemungutan pajak BBN-KB belum efektif, dikarenakan tidak terpenuhinya target penerimaan BBN-KB sepanjang tahun 2014 sampai 2018.

Tabel 2. Realisasi penerimaan pajak kendaraan bermotor (PKB) dan bea balik nama kendaraan bermotor (BBN-KB) Provinsi Jambi Tahun 2014-2018

\begin{tabular}{ccccccc}
\hline \multirow{2}{*}{ Tahun } & \multicolumn{3}{c}{ PKB (dalam Milivar Rp) } & \multicolumn{3}{c}{ BBN-KB (dalam Miliyar Rp) } \\
& Target & Realisasi & Ketercapaian(\%) & Target & Realisasi & Ketercapaian(\%) \\
\hline 2014 & 277,38 & 299,12 & 107,83 & 282,74 & 294,58 & 104,18 \\
2015 & 318,33 & 318,47 & 100,04 & 321,51 & 316,82 & 98,54 \\
2016 & 319,00 & 321,80 & 100,88 & 334,52 & 270,30 & 80,80 \\
2017 & 330,95 & 339,44 & 102,57 & 335,25 & 243,96 & 72,77 \\
2018 & 355,84 & 416,71 & 117,10 & 354,67 & 329,51 & 92,91 \\
\hline
\end{tabular}

Sumber: LAKIP SAMSAT Provinsi Jambi, 2017(diolah)

Belum efektifnya penerimaan BBNKB juga dikarenakan masih banyaknya kendaraan bermotor di Provinsi Jambi yang belum melakukan bea balik nama sepanjang tahun 2014-2018, yaitu 691.762 unit kendaraan. Sementara jumlah kendaraan yang telah melakukan bea balik nama sepanjang tahun 2014-2018, tercatat sebesar 172.940.

Di sisi lain hal yang perlu diperhatikan di dalam pemungutan PKB dan BBN-KB adalah aspek efisiensi. Menurut Dhinaryati (2003:25) efisiensi atau daya guna digunakan dengan menghitung perbandingan antara besarnya biaya yang digunakan untuk memungut pajak dan realisasi penerimaan pajak yang diterima oleh Badan Keuangan 
Daerah, yang dimaksud dengan biaya pemungutan pajak adalah pengeluaran operasional yang dikeluarkan oleh Badan Keuangan Daerah untuk merealisasikan penerimaan PKB dan BBN-KB. Adapun perbandingan antara realisasi penerimaan PKB dan BBN-KB dengan biaya operasional yang dikeluarkan BADAN KEUANGAN DAERAH Provinsi Jambi adalah sebagai berikut:

Tabel 3. Efisiensi pemungutan pajak kendaraan bermotor (PKB) dan bea balik nama kendaraan bermotor (BBN-KB) Provinsi Jambi Tahun 2014-2018

\begin{tabular}{ccccccc}
\hline Tahun & \multicolumn{2}{c}{ PKB (dalam Miliyar Rp) } & & \multicolumn{3}{c}{ BBN-KB (dalam Miliyar Rp) } \\
\cline { 5 - 7 } $\begin{array}{c}\text { Biaya } \\
\text { Operasional }\end{array}$ & Realisasi & $\begin{array}{c}\text { Nilai } \\
\text { Rasio }\end{array}$ & $\begin{array}{c}\text { Biaya } \\
\text { Operasional }\end{array}$ & Realisasi & $\begin{array}{c}\text { Nilai } \\
\text { Rasio }\end{array}$ \\
\hline 2014 & 5,16 & 299,12 & 1,73 & 5,16 & 294,58 & 1,75 \\
2015 & 18,90 & 318,47 & 5,93 & 18,90 & 316,82 & 5,96 \\
2016 & 18,55 & 321,80 & 5,76 & 18,55 & 270,30 & 6,86 \\
2017 & 23,01 & 339,44 & 6,78 & 23,01 & 243,96 & 9,43 \\
2018 & 29,52 & 416,71 & 7,09 & 29,52 & 329,51 & 8,96 \\
\hline
\end{tabular}

Sumber: LAKIP SAMSAT Provinsi Jambi, 2017(diolah)

Untuk mengetahui apakah pemungutan PKB dan BBN-KB dinyatakan efisien, menurut Dhinaryati (2003:25) jika nilai rasio antara biaya dengan realisasi penerimaan pajak lebih kecil dari satu, maka pemungutan PKB dan BBN-KB dapat dinyatakan efisien. Begitupula sebaliknya, jika nilai rasio antara biaya dengan realisasi penerimaan pajak lebih besar dari satu, maka pemungutan PKB dan BBN-KB dinyatakan tidak efisien. Berdasarkan data pada Tabel 3 menunjukkan bahwa pemungutan PKB dan BBNKB sepanjang tahun 2013 sampai 2014 dinilai tidak efisien, dikarenakan rasio antara biaya dengan realisasi penerimaan PKB dan BBN-KB lebih besar dari satu.

Merujuk pada permasalahan efektivitas dan efisiensi pemungutan PKB dan BBNKB di Provinsi Jambi sepanjang tahun 2013-2017, mengindikasikan masih kurang tepatnya cara yang digunakan dalam penetapan target penerimaan PKB dan BBN-KB. Hal ini dikarenakan penetapan target yang diterapkan cenderung mengacu pada elemen pertumbuhan penerimaan pajak dari tahun ke tahun dan pertumbuhan ekonomi daerah, tanpa menghitung secara akurat besarnya potensi riil penerimaan pajak yang bersangkutan dan besarnya biaya operasional yang efisien. Terbukti dari program pemutihan pajak kendaraan bermotor yang dilaksanakan pada tahun 2018 nyatanya belum mencapai target penerimaan PKB yang ditetapkan, dimana realisasi penerimaan PKB yang dicapai sebesar 76 miliyar rupiah dari 90 miliyar rupiah (target yang ditetapkan). Dari 1.839.000 unit kendaraan bermotor di Provinsi Jambi yang menunggak pembayaran PKB per Desember 2017, hanya 99.011 atau 5,38\% kendaraan bermotor yang dapat tertagih. Dengan demikian potensi penerimaan pajak dari sektor pajak PKB tertunggak masih sangat besar, dan perlu diupayakan peningkatannya melalui penetapan target penerimaan yang terukur dan strategi yang tepat.

Permasalahan khusus terkait penyusunan target penerimaan pajak termasuk pajak daerah seperti PKB dan BBN-KB adalah adanya upaya penetapan target penerimaan pajak sebagai dasar pemberian insentif (revenue targeting as an incentive device) bagi otoritas pajak. Permasalahan seperti ini bisa terjadi karena belum adanya acuan dan aturan formal yang menjelaskan bagaimana proses penentuan target penerimaan pajak dan menjelaskan secara tegas apa yang menjadi tanggung jawab otoritas pajak dalam proses tersebut. Oleh karena itu, perlu dilakukan evaluasi terhadap realisasi penerimaan pajak 
daerah khususnya PKB dan BBN-KB Provinsi Jambi ditinjau dari penetapan target penerimaan, efektivitas dan potensi penerimaan pajak, dan faktor penghambat maupun pendukung dalam pencapaian target penerimaan pajak, agar kedepannya dapat dirumuskan langkah-langkah terbaik yang dapat dilakukan dalam meningkatkan realisasi penerimaan pajak.

\section{METODE}

Metode penelitian yang digunakan dalam penelitian ini adalah metode deskriptif kuantitatif dengan pendekatan triangulasi, yang bertujuan untuk mendeskripsikan penetapan target dan efektivitas penerimaan pajak kendaraan bermotor (PKB) dan bea balik nama kendaraan bermotor (BBNKB) menurut potensi riil penerimaan pajak, serta faktor-faktor pendukung dan penghambat pencapaian target. Adapun sumber data dalam penelitian ini adalah Badan Pusat Statistik (BPS) Provinsi Jambi, kantor bersama Sistem Administrasi Manunggal Satu Atap (SAMSAT), dan Badan Keuangan Daerah Provinsi Jambi.

Data yang telah diperoleh kemudian dianalisis secara kualitatif maupun kuantitatif. Untuk mendeskripsikan penetapan target penerimaan pajak kendaraan bermotor (PKB) dan bea balik nama kendaraan bermotor (BBNKB), serta faktor-faktor yang diduga sebagai pendukung dan penghambat pencapaian target penerimaan kedua jenis pajak daerah tersebut, maka digunakan teknik analisis kualitatif model analisis interaktif, yang meliputi: (1) reduksi data, (2) penyajian data, dan (3) penarikan kesimpulan. Untuk menganalisis efektivitas penerimaan PKB dan BBNKB Provinsi Jambi, dilakukan melalui metode penetapan potensi dan pengukuran efektivitas, dengan langkah-langkah sebagai berikut:

Menentukan potensi penerimaan PKB dan BBNKB tahun 2014-2018 dengan menggunakan rumus sebagai berikut:

Efektivitas PKB $=\frac{\text { Realisasi penerimaan PKB tahun } " t "}{\text { Potensi } P K B \text { tahun } " t "} \times 100 \%$

Efektivitas BBNKB $=\frac{\text { Realisasi penerimaan } B B N K B \text { tahun } " t "}{\text { Potensi } B B N K B \text { tahun } " t "} \times 100 \%$

Dimana:

Potensi $\mathrm{PKB}=$ Jumlah kendaraan $\mathrm{X}$ NJKB $\mathrm{X}$ bobot $\mathrm{X}$ tarif pajak $\mathrm{PKB}$

Potensi BBNKB $=$ Jumlah kendaraan $\mathrm{X}$ NJKB $\mathrm{X}$ bobot $\mathrm{X}$ tarif pajak BBNKB

Untuk menentukan tingkat efektivitas penerimaan PKB dan BBNKB dapat memberikan peringkat dengan menggunakan metode skala peringkat (Siagian, 2014:234), dengan skala peringkat sebagai berikut:

Tabel 4. Tingkat efektivitas penerimaan PKB dan BBNKB

\begin{tabular}{cc}
\hline Skala peringkat $(\boldsymbol{\%})$ & Kriteria \\
\hline $90-100$ & Sangat Efektif \\
$80-89$ & Efektif \\
$70-79$ & Cukup Efektif \\
$60-69$ & Kurang Efektif \\
$0-59$ & Tidak Efektif
\end{tabular}

Sumber: Data diolah, 2020 
Untuk mengetahui hubungan efektivitas penerimaan PKB dan BBNKB terhadap pendapatan asli daerah Provinsi Jambi, baik secara parsial maupun simultan, maka digunakan teknik analisis korelasi Product moment dan analisis korelasi ganda. Signifikansi hubungan antara fektivitas penerimaan PKB dan BBNKB terhadap pendapatan asli daerah dapat diketahui melalui uji $\mathrm{t}$ statistik dan uji $\mathrm{F}$ statistik.

\section{HASIL DAN PEMBAHASAN}

\section{Penetapan target penerimaan PKB dan BBNKB di Provinsi Jambi}

Hasil wawancara yang dilakukan dengan pihak badan keuangan daerah Provinsi Jambi didapatkan keterangan bahwa metode penetapan target penerimaan PKB dan BBNKB baik di badan keuangan daerah Provinsi Jambi baik di Kota maupun di Kabupaten masih dilakukan secara manual berdasarkan data capaian/realisasi tahun terakhir ditambah dengan besaran persentase yang diperkirakan akan dicapai sesuai dengan trend peningkatan yang ada dari tahun - tahun sebelumnya. Adapun dasar menjadi pertimbangan dalam penetapan target penerimaan PKB dan BBNKB adalah: 1).Hasil analisis trend penerimaan PKB dan BBNKB tahun sebelumnya. 2). Menghitung potensi penerimaan PKB dan BBNKB berdasarkan data pertumbuhan pajak kendaraan bermotor baru dan kendaraan keluar-masuk. Adapun yang dimaksud dengan kendaraan masuk adalah kendaraan kendaraan plat $\mathrm{BH}$ yang melakukan balik nama menjadi $\mathrm{BH}$ dan kendaraan non-BH yang melakukan balik nama menjadi kendaraan dengan plat $\mathrm{BH}$. 3).Menganalisis masukan dan saran dari badan pengelola pajak dan retribusi daerah (BPPRD) dan SAMSAT Provinsi Jambi.

Target penerimaan PKB dan BBNKB merupakan salah satu bagian dari rumusan APBD sehingga proses formulasi kebijakan penetapan target penerimaan PKB dan BBNKB secara umum mengikuti alur dalam formulasi kebijakan APBD. Berdasarkan hasil penelitian, proses formulasi kebijakan penetapan target penerimaan PKB dan BBNKB di Provinsi Jambi secara garis besar dilakukan melalui beberapa tahapan, yaitu:

\section{Persiapan}

Tahapan persiapan dilakukan dengan menganalisis besarnya potensi PKB dan BBNKB melalui studi potensi. Analisis potensi jenis pajak daerah ini dilakukan dengan studi potensi oleh Badan Pengelola Pajak dan Retribusi Daerah (BPPRD) Provinsi Jambi bersama Badan Keuangan Daerah Provinsi Jambi melakukan perhitungan potensi PKB dan BBNKB dengan melihat statistik secara keseluruhan jumlah potensi PKB dan BBNKB di Provinsi Jambi. Selain itu, analisis potensi juga dilakukan dengan hasil proyeksi dan kajian ulang oleh BPPRD dan Badan Keuangan Daerah Provinsi Jambi.

\section{Pembahasan antara BPPRD dan badan keuangan daerah}

Selanjutnya, data-data yang dimiliki BPPRD dan badan keuangan daerah digabungkan melalui proses pembahasan untuk ditemukan kesepakatan besarnya target rasional dengan mempertimbangkan faktor-faktor yang mungkin terjadi di kemudian hari yang bisa mempengaruhi jumlah target penerimaan yang akan diajukan. Hasil dari pembahasan adalah draf pengajuan target penerimaan PKB dan BBNKB.

\section{Rumusan kebijakan oleh tim anggaran pemerintah daerah}

Setelah ditemukan kesepakatan antara BPPRD dan Badan Keuangan Daerah kemudian draf tersebut diajukan ke tim anggaran pemerintah daerah (TAPD). Oleh 
TAPD dilakukan pembahasan kembali dan jika ada kemungkinan perubahan akan dikembalikan lagi kepada pembahasan BPPRD dan Badan Keuangan Daerah. Jika tidak ada perubahan selanjutnya draf pengajuan target penerimaan PKB dan BBNKB tersebut akan dituangkan dalam Kebijakan Umum APBD serta Prioritas dan Plafon Anngaran Sementara (KUA-PPAS) yang selanjutnya akan diajukan ke tingkat legislatif.

\section{Proses legislasi}

Kemudian di tingkat legislatif akan melalui tahapan pembahasan di Komisi yang membidangi yaitu di Komisi II dan pembahasan di badan anggaran DPRD tingkat I maupun II.

\section{Pembahasan tingkat komisi}

Pembahasan di tingkat komisi memfokuskan pada pembahasan dan pemaparan potensi dan usulan dari eksekutif. Kemudian komisi akan mengevaluasi dan kemudian akan dilakukan adu argumentasi dengan referensi komisi mengenai besarnya target yang akan ditetapkan.

\section{Pembahasan di badan anggaran}

Selanjutnya besaran target penerimaan PKB dan BBNKB yang tertuang dalam KUA-PPAS yang sudah melalui pembahasan di Komisi II akan dilakukan pembahasan di tingkat badan anggaran DPRD. Pembahasan di badan anggaran DPRD difokuskan terhadap kelayakan target yang akan ditetapkan untuk dituangkan dalam Rancangan anggaran pendapatan dan belanja dareah (RAPBD). Jika kemudian badan anggaran mempunyai referensi sendiri, akan dilakukan permintaan data ulang atau argumentasi kembali antara badan anggaran dengan TAPD.

\section{Keputusan}

Setelah disepakati besarnya target penerimaan PKB dan BBNKB, maka keputusan di tingkat Badan Anggaran tersebut akan dicantumkan dalam RAPBD dan selanjutnya akan dievaluasi oleh Gubernur. Hasil evaluasi gubernur diserahkan kepada walikota dan bupati. Hasil penyempurnaan tersebut ditetapkan dalam Keputusan Pimpinan DPRD dan menjadi dasar penetapan peraturan daerah tentang APBD. Keputusan Pimpinan DPRD dimaksud bersifat final dan dilaporkan pada sidang paripurna untuk disahkan menjadi APBD yang di dalamnya termuat target penerimaan PKB dan BBNKB.

\section{Faktor pendukung dan penghambat dalam pencapaian target penerimaan $\mathrm{PKB}$ dan BBNKB di Provinsi Jambi}

Dalam meningkatkan pemungutan PKB dan BBNKB tentunya dalam pelaksanaannya terdapat faktor pendukung maupun faktor penghambat yang dihadapi oleh badan keuangan daerah Provinsi Jambi serta Sistem administrasi manunggal satu atap (SAMSAT) di Kota maupun Kabupaten untuk mencapai target penerimaan PKB dan BBNKB yang diharapkan. Adapun faktor pendukung yang diperoleh dari hasil wawancara adalah sebagai berikut:

\section{Struktur organisasi}

Struktur organisasi badan keuangan daerah Provinsi Jambi sudah dapat dikatakan baik, hal ini dapat dilihat sebagai berikut: (a) Bagian pendaftaran pada badan keuangan daerah Provinsi Jambi, telah memisahkan antara bagian pendaftaran dengan bagian pembayaran; dan b) Badan keuangan daerah Provinsi Jambi telah memisahkan fungsi dalam penanganan transaksi pemungutan pajak kendaraan bermotor. 


\section{Sistem organisasi dan prosedur pencatatan}

Dilihat dari sistem otorisasi badan keuangan daerah Provinsi Jambi sudah dinilai baik, hal ini dapat dilihat sebagai berikut; (a) Pembagian otorisasi kepada pejabat yang berwenang sudah diberikan sesuai dengan tanggung jawab, hal ini dapat dilihat dari pembentukan kelompok kerja pada mekanisme pengurusan PKB dan BBNKB, dan (b) Penerimaan kas telah di otorisasi oleh fungsi bagian pembayaran.

\section{Praktik yang sehat}

Praktik pemungutan PKB dan BBNKB sudah dikategorikan sebagai praktik yang sehat, yang ditandai oleh; (a) Formulir surat pendaftaran dan pendataan kendaraan bermotor (SPPKB) yang digunakan sudah menggunakan formulir surat pendaftaran dan pendataan kendaraan bermotor (SPPKB) yang bernomor urut tercetak, terlihat dari blanko pendaftaran dimana nomor unit tercetak dan setiap penggunaan blanko dicatat pada buku register secara berurut, (b) Pemeriksaan yang mendadak telah dilakukan dan sifatnya tidak rutin, jadi sesuai dengan kebutuhan, yang dilakukan oleh pejabat di lingkungan badan keuangan daerah Provinsi Jambi maupun oleh pejabat yang berwenang, (c) Ada bukti atau resi yang diberikan kepada wajib pajak oleh atas transaksi yang terjadi, (d) Penerimaan kas disetorkan pada hari yang sama atau paling lambat keesokan harinya. Faktor penghambat dalam pencapaian target penerimaan PKB dan BBNKB meliputi faktor internal dan faktor eksternal.

\section{Faktor internal}

Rendahnya dukungan/kerjasama instansi dalam pelayanan satu atap. Kurangnya komunikasi dan kerjasama yang baik antara instansi dalam SAMSAT sendiri. Salah satu contoh, dalam mekanisme pengesahan pembayaran PKB dan BBNKB di loket pengisian formulir hingga ke proses penelitian oleh polisi untuk memutuskan apakah dokumen wajib pajak dapat diterima, terkadang membutuhkan proses yang cukup lama dan sehingga menghambat proses di loket jasa raharja dan badan keuangan daerah sendiri. Terkadang salah satu instansi lebih memprioritaskan untuk memberikan pelayanan kepada wajib pajak yang dikenal oleh petugas yang bersangkutan. Hal ini menimbulkan ketidaknyamanan bagi wajib pajak untuk datang membayar pajak ke kantor.

\section{Produk hukum yang berubah-ubah}

Regulasi pemerintah yang berubah-ubah cukup menimbulkan kesulitan bagi pelaksana tugas dalam hal ini SAMSAT di Provinsi Jambi. Regulasi yang dimaksud misalnya seperti tidak ada aturan baku yang dapat dijadikan pegangan secara konsisten. Sebagai contoh, di tahun 2018 pemerintah dalam hal ini pemerintah Provinsi mengeluarkan kebijakan pemutihan pajak bahwa kendaraan yang sudah lama tidak melakukan pembayaran pajak akibat banyaknya denda yang harus ditanggung dapat diberikan keringanan seperti dapat kembali melaksanakan pembayaran pajak tanpa membayar denda yang terutang. Namun kebijakan yang dikeluarkan oleh pemerintah tersebut hanya sementara. Kebijakan yang berubah-ubah membuat kepercayaan wajib pajak dalam memenuhi kewajiban perpajakannya kepada pemerintah menurun.

\section{Peraturan mengenai tarif pajak progresif yang belum ada}

Untuk Provinsi Jambi, baik di Kota maupun Kabupaten, saat ini belum diberlakukan peraturan untuk meminimalisasi wajib pajak yang menghindari pajak progresif. Sehingga wajib pajak yang memiliki kendaraan bermotor lebih dari satu yang 
seharusnya dikenakan tarif pajak progresif sesuai dengan peraturan daerah yang berlaku tidak dapat terlaksana sesuai dengan peraturan yang ada karena belum ada kebijakan yang diberlakukan oleh pemerintah.

\section{Peraturan mutasi keluar-masuk kendaraan bermotor yang belum tegas}

Sebagian besar wajib pajak kendaraan bermotor yang akan melakukan mutasi kendaraan bermotor di Provinsi Jambi, kurang mengetahui prosedurnya sehingga banyak wajib pajak yang terlambat melaporkan kepada pemerintah bahwa akan melakukan mutasi dan menyebabkan wajib pajak dikenakan denda administrasi. Hal ini tentunya menghambat penerimaan dari pajak kendaraan bermotor

\section{Faktor eksternal}

\section{Pengaruh globalisasi ekonomi}

Globalisasi ekonomi yang terjadi mempengaruhi banyak faktor termasuk faktor perekonomian. Dengan adanya globalisasi ekonomi maka sektor perdagangan juga ikut menyesuaikan dengan kondisi yang ada. Salah satu dampak globalisasi ekonomi di sektor perekonomian yaitu ketika terjadi globalisasi para investor akan memindahkan investasi ke negara dengan pajak yang rendah sehingga penerimaan pajak mempengaruhi pertumbuhan ekonomi.

\section{Luasnya wilayah}

Luasnya wilayah yang menyebabkan badan keuangan daerah Provinsi Jambi harus membentuk unit pelayanan pendapatan daerah (UPPD), namun beberapa UPPD tidak dapat mencapai target yang telah ditentukan, karena banyak kendaraan yang belum terdaftar dalam pembayaran pajak kendaraan bermotor, sehingga pemungutan $\mathrm{PKB}$ yang di laksanakan oleh unit pelayanan pendapatan daerah (UPPD) dinilai kurang efektif.

\section{Wajib pajak belum memenuhi kewajiban perpajakannya}

Berdasarkan data yang ada, jumlah kendaraan bermotor di Provinsi Jambi sampai dengan tahun 2018 ada sebanyak 3.470.395. Berdasarkan data yang diperoleh dari Badan Keuangan Daerah Provinsi Jambi per 31 Desember 2018, dari 1.839.000 wajib pajak hanya 342.609 wajib pajak yang melakukan kewajibannya baik kendaraan roda 2 maupun roda 4. Hal tersebut tentunya sangat menghambat penerimaan Pajak Kendaraan Bermotor (PKB) di Provinsi Jambi, dan memberikan pengaruh yang cukup besar bagi pendapatan asli daerah, mengingat PKB merupakan pajak daerah yang memberikan kontribusi paling besar dibandingkan pajak dan retribusi daerah lainnya.

\section{Pertumbuhan penerimaan pajak kendaraan bermotor (PKB) di Provinsi Jambi tahun 2014-2018}

Laju pertumbuhan menunjukkan kemampuan daerah dalam mempertahankan dan meningkatkan keberhasilan daerah yang telah dicapainya dari periode ke periode berikutnya, diketahuinya pertumbuhan untuk masing-masing komponen sumber pendapatan dan pengeluaran dapat digunakan untuk mengevaluasi potensi-potensi yang perlu mendapat perhatian.

Data pada Tabel 5 menunjukkan bahwa penerimaan pajak kendaraan bermotor di Provinsi Jambi tahun 2014 hingga 2018 telah mengalami peningkatan setiap tahun. Laju pertumbuhan pajak kendaraan bermotor, yang diukur berdasarkan pertumbuhan bagi 
hasil pajak periode 2014-2018 menunjukkan pertumbuhan yang cukup positif, dengan rata-rata laju pertumbuhan sebesar 7,72\% per-tahun. Tahun 2015 laju pertumbuhan pajak sebesar 6,08\% turun menjadi 1,04\% pada tahun 2016. Tahun 2017 laju pertumbuhan pajak meningkat sebesar 5,19\%, hingga pada tahun 2018 mencapai laju pertumbuhan pajak yang tertinggi yaitu sebesar $18,56 \%$.

Tabel 5. Penerimaan pajak kendaraan bermotor di Provinsi Jambi Tahun 2014-2018

\begin{tabular}{cccc}
\hline Tahun & Penerimaan PKB (Rp) & Bagi Hasil Pajak (Rp) & $\begin{array}{c}\text { Pertumbuhan } \\
\text { Pajak (\%) }\end{array}$ \\
\hline 2014 & 299.120 .618 .198 & 89.736 .185 .459 & - \\
2015 & 318.470 .576 .871 & 95.541 .173 .061 & 6,08 \\
2016 & 321.804 .013 .917 & 96.541 .204 .175 & 1,04 \\
2017 & 339.437 .579 .667 & 101.831 .273 .900 & 5,19 \\
2018 & 416.782 .916 .243 & 125.034 .874 .873 & 18,56 \\
\hline Rata-rata & $\mathbf{3 3 9 . 1 2 3 . 1 4 0 . 9 7 9}$ & $\mathbf{1 0 1 . 7 3 6 . 9 4 2 . 2 9 4}$ & $\mathbf{7 , 7 2}$ \\
\hline
\end{tabular}

Sumber: Data diolah, 2020

\section{Pertumbuhan penerimaan bea balik nama kendaraan bermotor di Provinsi Jambi tahun 2014-2018}

Data pada Tabel 6 menunjukkan bahwa penerimaan BBNKB di Provinsi Jambi tahun 2014 hingga 2018 telah mengalami peningkatan setiap tahun. Laju pertumbuhan BBNKB, yang diukur berdasarkan pertumbuhan bagi hasil pajak periode 2014-2018 menunjukkan pertumbuhan yang fluktuatif, dengan rata-rata laju pertumbuhan sebesar 5,83\% per-tahun. Tahun 2015 merupakan tahun laju pertumbuhan BBNKB tertinggi yaitu sebesar $13,73 \%$, namun kemudian mengalami penurunan yang drastis menjadi 3,95\% pada Tahun 2016. Selanjutnya pada Tahun 2017 laju pertumbuhan pajak terus menurun hingga menjadi $0,16 \%$, dimana tahun ini merupakan tahun laju pertumbuhan BBNKB terendah. Pada Tahun 2018 laju pertumbuhan BBNKB kembali meningkat menjadi $5,47 \%$.

Tabel 6. Pertumbuhan penerimaan bea balik nama kendaraan bermotor di Provinsi Jambi Tahun 2014-2018

\begin{tabular}{cccc}
\hline Tahun & Penerimaan BBNKB (Rp) & Bagi Hasil Pajak (Rp) & $\begin{array}{c}\text { Pertumbuhan } \\
\text { Pajak (\%) }\end{array}$ \\
\hline 2014 & 277.381 .114 .500 & 83.214 .334 .350 & - \\
2015 & 321.514 .944 .320 & 96.454 .483 .296 & 13,73 \\
2016 & 334.723 .482 .000 & 100.417 .044 .600 & 3,95 \\
2017 & 335.256 .127 .369 & 100.576 .838 .211 & 0,16 \\
2018 & 354.672 .349 .210 & 106.401 .704 .763 & 5,47 \\
\hline Rata-rata & $\mathbf{3 2 4 . 7 0 9 . 6 0 3 . 4 8 0}$ & $\mathbf{9 7 . 4 1 2 . 8 8 1 . 0 4 4}$ & $\mathbf{5 , 8 3}$ \\
\hline
\end{tabular}

Sumber: Data diolah, 2020

Efektivitas penerimaan pajak kendaraan bermotor (PKB) di Provinsi Jambi

Hasil analisis efektivitas penerimaan PKB (Tabel 7) menunjukkan bahwa selama periode 2014-2018 penerimaan PKB di Provinsi Jambi tidak efektif, jika dilihat dari rasio realisasi penerimaan PKB dengan potensi penerimaan PKB. Berdasarkan hasil perhitungan nilai rata-rata persentase efektivitas yaitu sebesar $23,41 \%$ per-tahun, 
mengindikasikan bahwa realisasi penerimaan PKB setiap tahunnya jauh lebih kecil dibandingkan potensi penerimaan PKB di Provinsi Jambi. Hal ini berarti target penerimaan PKB yang ditetapkan sepanjang tahun 2014-2018 belum sepenuhnya disesuaikan dengan potensi rill penerimaan PKB.

Tabel 7. Efektivitas penerimaan pajak kendaraan bermotor (PKB) di Provinsi Jambi Tahun 2014-2018

\begin{tabular}{cccccc}
\hline No. & Tahun & Potensi PKB & Realisasi PKB & $\begin{array}{c}\text { Efektivitas } \\
(\boldsymbol{\%})\end{array}$ & Kriteria \\
\hline 1 & 2014 & 1.267 .343 .123 .933 & 299.120 .618 .198 & 23,60 & Tidak Efektif \\
2 & 2015 & 1.344 .274 .261 .621 & 318.470 .576 .871 & 23,69 & Tidak Efektif \\
3 & 2016 & 1.351 .357 .183 .347 & 321.804 .013 .917 & 23,81 & Tidak Efektif \\
4 & 2017 & 1.507 .698 .944 .950 & 339.437 .579 .667 & 22,51 & Tidak Efektif \\
5 & 2018 & 1.777 .364 .809 .871 & 416.782 .916 .243 & 23,45 & Tidak Efektif \\
\hline
\end{tabular}

Sumber: Data diolah, 2020

\section{Efektivitas penerimaan bea balik nama kendaraan bermotor (BBNKB) di Provinsi Jambi}

Hasil analisis efektivitas penerimaan BBNKB (Tabel 8) juga menunjukkan bahwa penerimaan BBNKB di Provinsi Jambi dari tahun 2014 hingga 2018 tidak efektif. Efektivitas penerimaan ini juga didasarkan atas rasio realisasi penerimaan BBNKB dengan potensi penerimaan BBNKB di Provinsi Jambi. Berdasarkan hasil perhitungan nilai rata-rata persentase efektivitas penerimaan $\mathrm{BBNKB}$ yaitu sebesar 19,27\% per-tahun, mengindikasikan bahwa realisasi penerimaan BBNKB setiap tahunnya jauh lebih kecil dibandingkan potensi penerimaan BBNKB di Provinsi Jambi. Hal ini berarti target penerimaan BBNKB yang ditetapkan sepanjang tahun 2014-2018 juga belum sepenuhnya disesuaikan dengan potensi rill penerimaan BBNKB.

Tabel 8. Efektivitas penerimaan bea balik nama kendaraan bermotor (BBNKB) di Provinsi Jambi Tahun 2014-2018

\begin{tabular}{cccccc}
\hline No. & Tahun & Potensi BBNKB & Realisasi BBNKB & Efektivitas(\%) & Kriteria \\
\hline 1 & 2014 & 1.933 .701 .918 .704 & 277.381 .114 .500 & 14,34 & Tidak Efektif \\
2 & 2015 & 1.652 .303 .628 .568 & 321.514 .944 .320 & 19,46 & Tidak Efektif \\
3 & 2016 & 1.552 .602 .348 .800 & 334.723 .482 .000 & 21,56 & Tidak Efektif \\
4 & 2017 & 1.669 .508 .466 .698 & 335.256 .127 .369 & 20,08 & Tidak Efektif \\
5 & 2018 & 1.696 .370 .255 .285 & 354.672 .349 .210 & 20,91 & Tidak Efektif \\
\hline
\end{tabular}

Sumber: Data diolah, 2020

\section{Analisis tingkat kontribusi pajak kendaraan bermotor (PKB) terhadap pendapatan asli daerah Provinsi Jambi tahun 2014-2018}

Kontribusi pajak daerah merupakan sumbangan yang diberikan berupa uang atau yang lainnya kepada daerah sesuai Peraturan Undang-Undang untuk membiayai rumah tangga daerah. Pajak Kendaraan Bermotor merupakan pajak provinsi. Pajak tersebut akan diukur kontribusinya terhadap Pendapatan Asli Daerah Provinsi Jambi berdasarkan jumlah dana bagi hasil pajak daerah ke provinsi dibandingkan dengan Pendapatan Asli Daerah di Provinsi Jambi. 
Tabel 9. Kontribusi penerimaan pajak kendaraan bermotor terhadap pendapatan asli daerah Provinsi Jambi Tahun 2014-2018

\begin{tabular}{ccccc}
\hline Tahun & $\begin{array}{c}\text { Bagi Hasil PKB } \\
(\mathbf{R p})\end{array}$ & Pendapatan Asli Daerah (Rp) & $\begin{array}{c}\text { Kontribusi } \\
(\boldsymbol{\%})\end{array}$ & Kriteria \\
\hline 2014 & 89.736 .185 .459 & 1.281 .239 .472 .808 & 7,00 & Sangat kurang \\
2015 & 95.541 .173 .061 & 1.238 .318 .627 .206 & 7,72 & Sangat kurang \\
2016 & 96.541 .204 .175 & 1.232 .784 .078 .663 & 7,83 & Sangat kurang \\
2017 & 101.831 .273 .900 & 1.393 .072 .790 .798 & 7,31 & Sangat kurang \\
2018 & 125.034 .874 .873 & 1.494 .530 .066 .299 & 8,37 & Sangat kurang \\
\hline \multicolumn{3}{c}{ Rata-rata } & \multicolumn{3}{c}{$\mathbf{7 , 6 5}$} \\
\hline
\end{tabular}

Sumber: Data diolah, 2020

Data pada Tabel 9 menunjukkan bahwa kontribusi penerimaan PKB terhadap PAD Provinsi Jambi sepanjang tahun 2014-2018, berada pada tingkat kontribusi dengan kriteria "sangat kurang", dengan rata-rata persentase kontribusi sebesar 7,65\%. Sangat rendahnya kontribusi penerimaan $\mathrm{PKB}$ ini dikarenakan realisasi maupun penetapan target penerimaan PKB belum sepenuhnya disesuaikan dengan potensi penerimaan PKB di Provinsi Jambi

\section{Analisis tingkat kontribusi bea balik nama kendaraan bermotor terhadap pendapatan asli daerah Provinsi Jambi Tahun 2014-2018}

Berdasarkan Peraturan Gubernur Jambi Nomor 14 Tahun 2016 tentang Pembagian Dana Bagi Hasil Penerimaan Pajak Pemerintah Provinsi untuk Kabupaten / Kota dalam Provinsi Jambi Pasal 1, bagi hasil Bea Balik Nama Kendaraan Bermotor sebesar 30\% dibagikan kepada kabupaten/kota. Berdasarkan Tabel 10, penerimaan bagi hasil Bea Balik Nama Kendaraan Bermotor Provinsi Jambi baik di Kota maupun Kabupaten tahun 2014 sampai 2018 cenderung meningkat. Namun, dari hasil analisis tingkat kontribusi BBNKB terhadap PAD Provinsi Jambi, yang diukur berdasarkan jumlah dana bagi hasil pajak daerah ke provinsi dibandingkan dengan Pendapatan Asli Daerah di Provinsi Jambi, menunjukkan bahwa masih sangat kurangnya kontribusi penerimaan BBNKB terhadap PAD Provinsi Jambi sepanjang tahun 2014-2018, dengan rata-rata persentase kontribusi sebesar 7,35\%. Sangat rendahnya kontribusi penerimaan BBNKB ini juga dikarenakan realisasi maupun penetapan target penerimaan BBNKB belum sepenuhnya disesuaikan dengan potensi penerimaan BBNKB di Provinsi Jambi.

Tabel 10. Kontribusi penerimaan bea balik nama kendaraan bermotor, pendapatan asli daerah Provinsi Jambi Tahun 2014-2018

\begin{tabular}{ccccc}
\hline Tahun & $\begin{array}{c}\text { Bagi Hasil } \\
\text { BBNKB (Rp) }\end{array}$ & Pendapatan Asli Daerah (Rp) & Kontribusi (\%) & Kriteria \\
\hline 2014 & 83.214 .334 .350 & 1.281 .239 .472 .808 & 6,49 & Sangat kurang \\
2015 & 96.454 .483 .296 & 1.238 .318 .627 .206 & 7,79 & Sangat kurang \\
2016 & 100.417 .044 .600 & 1.232 .784 .078 .663 & 8,15 & Sangat kurang \\
2017 & 100.576 .838 .211 & 1.393 .072 .790 .798 & 7,22 & Sangat kurang \\
2018 & 106.401 .704 .763 & 1.494 .530 .066 .299 & 7,12 & Sangat kurang \\
\hline \multicolumn{5}{c}{ Rata-rata } \\
\hline
\end{tabular}

Sumber: Data diolah, 2020 


\section{Hubungan efektivitas penerimaan PKB \& BBNKB terhadap PAD Provinsi Jambi}

Hasil analisis korelasi antara efektivitas penerimaan PKB dan efektivitas penerimaan BBNKB terhadap PAD, baik secara parsial maupun secara simultan memiliki nilai korelasi positif. Hal ini dibuktikan dari hasil pengujian pada Tabel 11 dan Tabel 12.

Tabel 11. Hasil analisis korelasi sederhana efektivitas penerimaan PKB dan efektivitas penerimaan BBNKB terhadap PAD

\begin{tabular}{llcc}
\hline No. & Variabel & Koefisien korelasi $\left(\mathbf{R}_{\text {xiy }}\right)$ & $\mathbf{t}_{\text {statistik }}$ \\
\hline 1 & Efektivitas PKB terhadap PAD & 0,411 & 0,780 \\
2 & Efektivitas BBNKB terhadap PAD & 0,833 & 2,609 \\
\hline
\end{tabular}

Sumber: Data diolah, 2020

Data pada Tabel 11 menunjukkan nilai koefisien korelasi $\left(\mathrm{R}_{\mathrm{x} 1 \mathrm{y}}\right)$ antara efektivitas penerimaan PKB terhadap PAD sebesar 0,411, dimana nilai ini berada pada rentang 0,410,70 dengan kriteria tingkat korelasi "sedang". Namun, dari hasil uji t statistik didapatkan nilai $t_{\text {statistik }}$ sebesar 0,780 , dimana nilai ini lebih kecil dari nilai $t_{\text {tabel }}(4,303)$. Dengan demikian didapatkan keputusan untuk menolak hipotesis, yang berarti bahwa efektivitas penerimaan PKB secara parsial tidak memiliki hubungan yang signifikan dengan pendapatan asli daerah (PAD) Provinsi Jambi.

Hasil pengujian lainnya (Tabel 11) menunjukkan nilai koefisien korelasi $\left(\mathrm{R}_{\mathrm{x} 2 \mathrm{y}}\right)$ antara efektivitas penerimaan BBNKB terhadap PAD sebesar 0,833 , dimana nilai ini berada pada rentang 0,70-0,90 dengan kriteria tingkat korelasi "tinggi". Namun, dari hasil uji t statistik didapatkan nilai $t_{\text {statistik }}$ sebesar 2,609, dimana nilai ini lebih kecil dari nilai $t_{\text {tabel }}$ (4,303). Dengan demikian didapatkan keputusan untuk menolak hipotesis, yang berarti bahwa efektivitas penerimaan BBNKB secara parsial tidak memiliki hubungan yang signifikan dengan pendapatan asli daerah (PAD) Provinsi Jambi.

Tabel 12. Hasil analisis korelasi ganda efektivitas penerimaan $\mathrm{PKB}$ dan efektivitas penerimaan BBNKB terhadap PAD

\begin{tabular}{clcc}
\hline No. & & Koefisien korelasi $\left(\mathbf{R}_{\mathbf{y x 1 . x} \mathbf{2})}\right.$ & F $_{\text {statistik }}$ \\
\hline \multirow{2}{*}{1} & Efektivitas PKB dan & 0,892 & 3,892 \\
& BBNKB terhadap PAD & & \\
\hline
\end{tabular}

Sumber: Data diolah, 2020

Data pada Tabel 12 menunjukkan nilai koefisien korelasi $\left(\mathrm{R}_{\mathrm{yx} 1 . \mathrm{x} 2}\right)$ antara efektivitas penerimaan PKB dan efektivitas penerimaan BBNKB terhadap PAD sebesar 0,892, dimana nilai ini berada pada rentang 0,70-0,90 dengan kriteria tingkat korelasi "tinggi". Namun, dari hasil uji F statistik didapatkan nilai $F_{\text {statistik }}$ sebesar 3,892, dimana nilai ini lebih kecil dari nilai $F_{\text {tabel }}(19,00)$. Dengan demikian didapatkan keputusan untuk menolak hipotesis, yang berarti bahwa efektivitas penerimaan PKB dan efektivitas penerimaan BBNKB secara simultan tidak memiliki hubungan yang signifikan dengan pendapatan asli daerah (PAD) Provinsi Jambi.

\section{Pembahasan}

Pajak kendaraan bermotor (PKB) dan bea balik nama kendaraan bermotor (BBNKB) merupakan sumber pendapatan daerah terbesar untuk sektor pajak daerah. Hal ini terjadi karena seiring dengan pertambahan penduduk setiap tahun, menyebabkan 
meningkatnya ketergantungan terhadap kebutuhan akan alat transportasi seperti kendaraan bermotor baik roda empat maupun roda dua. Oleh karena itu, penetapan target penerimaan PKB dan BBNKB di setiap daerah harus didasarkan pada kondisi-kondisi sebenarnya agar target yang telah ditetapkan bisa mendekati potensi riil serta sesuai dengan kemampuan daerah dalam pemungutannya.

Berdasarkan hasil temuan yang telah diuraikan sebelumnya, bahwa penetapan target penerimaan PKB dan BBNKB baik di Badan Keuangan Daerah Provinsi Jambi baik di Kota maupun di Kabupaten masih dilakukan secara manual berdasarkan data capaian/realisasi tahun terakhir ditambah dengan besaran persentase yang diperkirakan akan dicapai sesuai dengan trend peningkatan yang ada dari tahun - tahun sebelumnya. Salah satu yang menjadi dasar pertimbangan dalam penetapan target penerimaan PKB dan BBNKB adalah hasil perhitungan potensi penerimaan PKB dan BBNKB berdasarkan data pertumbuhan pajak kendaraan bermotor baru dan kendaraan keluar-masuk.

Namun, dari hasil analisis efektivitas penerimaan PKB (Tabel 5.4) dan efektivitas penerimaan BBNKB (Tabel 13) menunjukkan bahwa penetapan target penerimaan PKB dan BBNKB sepanjang tahun 2014-2018 belum sepenuhnya disesuaikan dengan potensi rill penerimaan $\mathrm{PKB}$ dan $\mathrm{BBNKB}$. Hal ini dibuktikan dari rata-rata persentase efektivitas penerimaan PKB yang hanya mencapai $23,41 \%$ dengan kategori "tidak efektif". Begitupula rata-rata persentase efektivitas penerimaan BBNKB yang hanya mencapai 19,27\% dengan kategori "tidak efektif".

Tabel 13. Perbandingan PKB dan BBNKB Provinsi Jambi Tahun 2014-2018

\begin{tabular}{|c|c|c|c|c|c|c|}
\hline Tahun & $\begin{array}{c}\text { Target } \\
\text { Penerimaan } \\
\text { PKB (Rp) }\end{array}$ & $\begin{array}{c}\text { Potensi } \\
\text { Penerimaan PKB } \\
(\mathbf{R p})\end{array}$ & $\begin{array}{c}\text { Persentase } \\
(\%)\end{array}$ & $\begin{array}{c}\text { Target } \\
\text { Penerimaan } \\
\text { BBNKB (Rp) }\end{array}$ & $\begin{array}{c}\text { Potensi } \\
\text { Penerimaan } \\
\text { BBNKB (Rp) }\end{array}$ & $\begin{array}{c}\text { Persentase } \\
(\%)\end{array}$ \\
\hline 2014 & 277.380 .000 .000 & 1.267.343.123.933 & 21,89 & 282.740 .000 .000 & 1.933.701.918.704 & 14,62 \\
\hline 2015 & 318.330 .000 .000 & 1.344.274.261.621 & 23,68 & 321.510 .000 .000 & 1.652 .303 .628 .568 & 19,46 \\
\hline 2016 & 319.000 .000 .000 & 1.351 .357 .183 .347 & 23,61 & 334.520 .000 .000 & 1.552 .602 .348 .800 & 21,55 \\
\hline 2017 & 330.950 .000 .000 & 1.507 .698 .944 .950 & 21,95 & 335.250 .000 .000 & 1.669 .508 .466 .698 & 20,08 \\
\hline 2018 & 355.840 .000 .000 & 1.777.364.809.871 & 20,02 & 354.670 .000 .000 & 1.696 .370 .255 .285 & 20,91 \\
\hline \multicolumn{3}{|c|}{ Rata-rata $(\%)$} & 22,23 & \multicolumn{2}{|c|}{ Rata-rata $(\%)$} & 19,32 \\
\hline
\end{tabular}

Sumber: Data diolah, 2020

Data pada Tabel 13 menunjukkan bahwa rata-rata persentase rasio target penerimaan PKB terhadap potensi penerimaan PKB tahun 2014-2018 hanya sebesar $22,23 \%$. Sementara rata-rata persentase rasio target penerimaan BBNKB terhadap potensi penerimaan BBNKB tahun 2014-2018 sebesar 19,32\%. Merujuk pada kriteria tingkat efektivitas penerimaan PKB dan BBNKB menurut Siagian (2014:234), bahwa penerimaan $\mathrm{PKB}$ dan BBNKB dapat dinyatakan cukup efektif, jika realiasi penerimaan pajak tersebut mencapai $70 \%$ hingga $79 \%$ dari potensi penerimaan pajak. Dengan demikian, ketidakefektivan penerimaan PKB dan BBNKB sesungguhnya dikarenakan target yang ditetapkan jauh di bawah skala peringkat efektivitas penerimaan PKB dan BBNKB, sebagaimana yang dijelaskan oleh (Siagian, 2014:234). Namun, bila melihat perbandingan antara realisasi penerimaan $\mathrm{PKB}$ dan BBNKB dengan target penerimaan PKB dan BBNKB (Tabel 1.2) menunjukkan bahwa realisasi penerimaan PKB dan BBNKB sepanjang tahun 2014-2018 dapat dinyatakan efektif. Hal ini didasari atas pendapat Kristianti dan Jati (2015) dalam penelitiannya bahwa efektivitas adalah menggambarkan tingkat pencapaian hasil program dengan target yang ditetapkan. Selain 
itu, hasil penelitian Susena dan Nurzam (2014) juga menggunakan rasio target penerimaan $\mathrm{PKB}$ dan BBNKB dengan realisasi penerimaan PKB dan BBNKB, sebagai dasar dalam pengukuran efektivitas penerimaan pajak.

\section{KESIMPULAN DAN SARAN}

\section{Kesimpulan}

Penetapan target penerimaan PKB dan BBNKB tahun 2014-2018 di Provinsi Jambi belum disesuaikan sepenuhnya dengan potensi penerimaan PKB dan BBNKB. Faktor pendukung yang dimiliki Badan Keuangan Daerah Provinsi Jambi serta Sistem Administrasi Manunggal Satu Atap (SAMSAT) di kota maupun kabupaten untuk mencapai target penerimaan PKB dan BBNKB yang diharapkan, meliputi; (1) struktur organisasi yang telah tertata dengan baik (2) sistem organisasi dan prosedur pencatatan yang sudah baik, dan (3) Praktik pemungutan PKB dan BBNKB yang sehat. sedangkan faktor penghambat dalam pencapaian target penerimaan PKB dan BBNKB meliputi; (1) rendahnya dukungan/kerjasama instansi dalam pelayanan satu atap, (2) produk hukum yang berubah-ubah, (3) Peraturan mengenai tarif pajak progresif yang belum ada, (4) peraturan mutasi keluar-masuk kendaraan bermotor yang belum tegas, (5) pengaruh globalisasi ekonomi, (6) Luasnya wilayah yang tidak sesuai dengan kapasitas unit pelayanan pendapatan daerah (UPPD) untuk mencapai target penerimaan pajak yang telah ditentukan, (7) Rendahnya kesadaran wajib pajak dalam membayar pajak PKB dan BBNKB.

Penerimaan PKB dan BBNKB tahun 2014-2018 di Provinsi Jambi belum efektif menurut potensi penerimaan PKB dan BBNKB. Efektivitas penerimaan PKB dan $\mathrm{BBNKB}$, baik secara parsial maupun secara simultan, memiliki hubungan yang tidak signifikan terhadap pendapatan asli daerah (PAD) Provinsi Jambi Tahun 2014-2018.

\section{Saran}

Berdasarkan hasil analisis efektivitas penerimaan PKB dan BBNKB, maka peneliti memberikan rekomendasi kepada badan keuangan daerah Provinsi Jambi untuk perbaikan dalam perumusan kebijakan penetapan target penerimaan PKB dan BBNKB, yaitu dengan menyesuaikan dan memperhitungkan kembali tax gap dan potensi pajak, serta faktor-faktor yang mempengaruhi efektivitas peneriman pajak yaitu; kepatuhan Wajib Pajak, kemampuan administrasi dinas pajak, sistem informasi Wajib Pajak, dan kinerja implementasi pemungutan pajak.

Badan keuangan daerah Provinsi Jambi juga perlu melakukan kerjasama dengan dealer dan finance untuk pendataan kendaraan bermotor. Dealer dan finance diwajibkan untuk memberikan keterangan lengkap tentang data seperti alamat pemilik kendaraan bermotor misalnya sistem komputerisasi BP2RD bisa mengakses data dari dealer atau finance yang ada di Provinsi Jambi untuk data pembeli kendaraan bermotor. Sehinga jika ada wajib pajak yang belum atau tidak membayar pajak bisa ditelusuri melalui alamat yang terdaftar di finance atau dealer tersebut.

Bagi peneliti selanjutnya diharapkan dapat melakukan penelitian lebih luas tentang pajak daerah, baik dalam hal evaluasi penerimaan pajak maupun peningkatan pendapatan asli daerah, berhubung dalam penelitian ini peneliti hanya memfokuskan pada dua variabel yaitu pajak kendaraan bermotor (PKB) dan bea balik nama kendaraan bermotor (BBNKB). 


\section{DAFTAR PUSTAKA}

Dhinaryati. (2003). Analisis efektifitas dan efisiensi PAD di Era Otonomi Daerah Kota Surakarta. Artikel Penelitian: Surakarta

Gunawan, E. (2018). Pengaruh efektivitas penerimaan pajak daerah dan retribusi daerah terhadap pendapatan asli daerah Kabupaten Aceh Timur. Jurnal Ekonomi dan Manajemen Teknologi, 2 (1):28-37

Halim, A. (2004). Bunga rampai manajemen keuangan daerah. Edisi Revisi. UPP AMP YKPN: Yogyakarta

Ilyas, W.B. dan Waluyo. (2011). Perpajakan indonesia (buku satu). Salemba Empat: Jakarta:

Lenri, R. dan Pamungkas, H. (2014). Evaluasi penerimaan pajak kendaraan bermotor dalam rangka meningkatkan pendapatan daerah (Studi kasus samsat kota manado periode 2012-2014). Artikel Penelitian, Universitas Bina Nusantara

Mangkoesoebroto, G. (2001). Ekonomi publik. Edisi 3. FE UGM: Yogyakarta

Mardiasmo. (2002). Otonomi dan manajemen keuangan daerah. Andi: Yogyakarta.

Miles, M.B, Huberman, A.M., dan Saldana, J. (2014). Qualitative data analysis, a methods sourcebook, Edition 3. USA: Sage Publications. Terjemahan Tjetjep Rohindi Rohidi, UI-Press: Jakarta

Mokoginta, N.C. (2015). Analisis efektivitas prosedur pemungutan pajak kendaraan bermotor dan bea balik nama kendaraan bermotor dalam peningkatan PAD Provinsi Sulawesi Utara. Jurnal EMBA, 3 (1), 685-694

Moleong, L.J. (2011). Metodologi penelitian kualitatif. Remaja Rosdakarya: Bandung

Shifa, V.S., dan Anwar, Y. (2013). Evaluasi penerimaan pajak kendaraan bermotor (studi kasus SAMSAT Jakarta Pusat). Fakultas Ekonomi, Universitas Bina Nusantara

Umiyati. E., A Amril., \& Zulfanetti.Z. (2017). Pengaruh belanja modal, pertumbuhan ekonomi dan jumlah penduduk miskin terhadap indeks pembangunan manusia di Kabupaten/Kota Provinsi Jambi. Jurnal Sains Sosio Humaniora, 1 (1), 29-37

Undang-Undang Nomor 28 Tahun 2009 tentang pajak daerah dan retribusi daerah

Undang-Undang Republik Indonesia Nomor 33 Tahun 2004 tentang perimbangan keuangan antara pemerintah pusat dan pemerintah daerah

Undang-Undang Republik Indonesia Nomor 34 Tahun 2000 tentang pajak dan retribusi daerah

Waluyo. (2010). Perpajakan indonesia, Edisi 9. Salemba Empat: Jakarta

Zamzami., \& Hastuti.D. (2019). Determinan penerimaan daerah dan pertumbuhan ekonomi terhadap pengembangan ekonomi kreatif di Provinsi Jambi. Jurnal Paradigma Ekonomika 13 (1), 37-45 